\title{
Comparison of Properties of Fresh and Hardened Concrete Containing Finely Ground Glass Powder, Fly Ash, or Silica Fume
}

\author{
Rungrawee Wattanapornprom ${ }^{\mathrm{a}}$, and Boonchai Stitmannaithum ${ }^{\mathrm{b}}$ \\ Faculty of Engineering, Chulalongkorn University, Bangkok Thailand \\ E-mail: a rungrawee.w@gmail.com (Corresponding author), bboonchai.s@chula.ac.th
}

\begin{abstract}
Waste glass has potential for use in building materials, for example, as an aggregate replacement, a filler in concrete, or a cement replacement. Finely ground glass powder (particle size of less than $38 \mu \mathrm{m}$ ) can be used as a pozzolan material in concrete because of its high reactive silica content. This paper studied the properties of concrete containing finely ground glass powder (approximate particle size, $12-15 \mu \mathrm{m}$ ) of admixture Type D following ASTM C494. The fresh concrete's compressive strength, ability to resist chloride penetration, and free drying shrinkage were evaluated. The experiment showed that using $10 \%$ or $20 \%$ glass powder reduced the workability of fresh concrete and accelerated its setting time. However, concrete containing $10 \%$ finely ground glass powder exhibited greater compressive strength and improved resistance to the penetration of chloride ions than normal concrete and concrete containing fly ash at the same replacement level. Concrete with 10\% glass powder also had lower shrinkage than normal concrete and concrete containing fly ash but higher shrinkage than concrete with $10 \%$ silica fume.
\end{abstract}

Keywords: Finely ground glass powder, free shrinkage, chloride resistance, fly ash, silica fume compressive strength development.

ENGINEERING JOURNAL Volume 19 Issue 3

Received 27 May 2015

Accepted 27 May 2015

Published 5 June 2015

Online at http://www.engj.org/

DOI:10.4186/ej.2015.19.3.35 


\section{Introduction}

Pozzolan is an additive used in concrete to improve its quality, for example, to improve the workability, reduce the temperature rise during initial hydration, and improve the strength development and durability of concrete materials [1-4]. Several types of pozzolan are widely used, such as natural pozzolan, fly ash, blast furnish slag, and silica fume (microsilica) [4].

Many studies have shown that waste glass has potential for use in building material, for example, as an aggregate replacement, a filler in concrete, or a cement replacement [5-13]. Specifically, finely ground glass powder (particle size of less than $38 \mu \mathrm{m}$ ) has potential for use as pozzolan, and glass powder has more reactive silica than fly ash, which is the most commonly used pozzolan in Thailand [14]. In addition, glass powder tended to improve the compressive strength more if it was more finely ground [6].

In Thailand in 2009, there were almost 1.76 million metric tons of waste glasses in the waste system, and only 1.28 million metric tons, or 73\%, were reused and recycled [15]. Not all of the waste glass can be recycled because of impurities or mixed colors, and the remainder of the waste glass was mostly land-filled. [7]. Systems for collecting, cleaning, sieving, and recycling waste glass exist in Thailand, and many recycling companies are located throughout the country [11]. The use of waste glass in concrete as an additive material can reduce the amount of waste glass in the waste system and increase the available pozzolanic materials in the country.

This research studies the properties of concrete made with $10 \%$ or $20 \%$ finely ground glass powder (average particle size, $12-15 \mu \mathrm{m}$ ) and compares them with those of concrete containing $10 \%$ or $20 \%$ fly ash and $10 \%$ silica fume by testing the setting time, slump, and compressive strength development of concrete at $1,3,7,14$, and 28 days and the durability of concrete, including its ability to resist chloride penetration and free drying shrinkage.

\section{Material Properties}

\subsection{Cement}

Type I ordinary Portland cement conforming to ASTM C150 was used in this study. The physical properties and chemical composition of the cement materials are shown in Tables 1 and 2, respectively. The shape of the cement particles is shown in Fig. 1(a).

\subsection{Additive Materials}

\subsubsection{Glass Powder}

The waste glass used in this study was soda-lime clear glass from used soda bottles. Crushed waste glass 2.5 $\mathrm{cm}$ in size was ground in a ball mill grinder until the mean particle size, as measured by a particle size distribution machine, was between 12 and $15 \mu \mathrm{m}$. The particle size was calculated using Fraunhofer's equation with the $\mathrm{D}(4,3)$ method.

\subsubsection{Fly Ash}

The fly ash used in this study was obtained from the Mae Moh electrical power plant in the north of Thailand.

\subsubsection{Silica Fume}

The silica fume used in the study is the densified type following ASTM C1240-05 [16].

The physical properties and chemical composition of the additive materials are shown in Tables 1 and 2, respectively. The shapes of the additive materials are shown in Fig. 1(b)-1(d). 
Table 1. Physical properties of ordinary Portland cement (OPC), glass powder (GP), fly ash (FA), and silica fume (SF) used in this study.

\begin{tabular}{lcccc}
\hline Physical properties & OPC & GP & FA & SF \\
\hline Specific Gravity & 3.15 & 2.51 & 2.36 & 2.28 \\
\hline Mean Diameter $(\mu \mathrm{m})$ & 26.06 & 12.3 & 26.39 & 234.48 \\
\hline Wet Sieve Passing 325 Mesh (\% mass) & - & 100 & 66.2 & 92.1 \\
\hline
\end{tabular}

Table 2. Chemical composition of cement, glass powder, fly ash, and silica fume used in this study obtained by X-ray fluorescence spectrometry.

\begin{tabular}{lcccc}
\hline $\begin{array}{c}\text { Oxide } \\
\text { \% By Weight }\end{array}$ & OPC & GP & FA & SF \\
\hline $\mathrm{SiO}_{2}$ & 19.74 & 65.66 & 41.18 & 87.34 \\
\hline $\mathrm{Al}_{2} \mathrm{O}_{3}$ & 5.14 & 1.32 & 22.06 & 0.77 \\
\hline $\mathrm{Fe}_{2} \mathrm{O}_{3}$ & 3.15 & 0.14 & 12.03 & 4.09 \\
\hline $\mathrm{CaO}$ & 64.95 & 11.42 & 14.89 & 1.03 \\
\hline $\mathrm{MgO}$ & 0.90 & 1.98 & 2.69 & 1.18 \\
\hline $\mathrm{SO}$ & 2.51 & 0.21 & 2.52 & 0.35 \\
\hline $\mathrm{LOI}$ & 2.47 & - & 0.21 & 3.53 \\
\hline $\mathrm{Na}_{2} \mathrm{O}$ & 0.13 & 18.87 & 1.15 & 0.02 \\
\hline $\mathrm{K}_{2} \mathrm{O}$ & 0.52 & 0.25 & 2.33 & 0.93 \\
\hline Free $\mathrm{CaO}$ & 0.71 & - & 0.22 & 0.01 \\
\hline
\end{tabular}

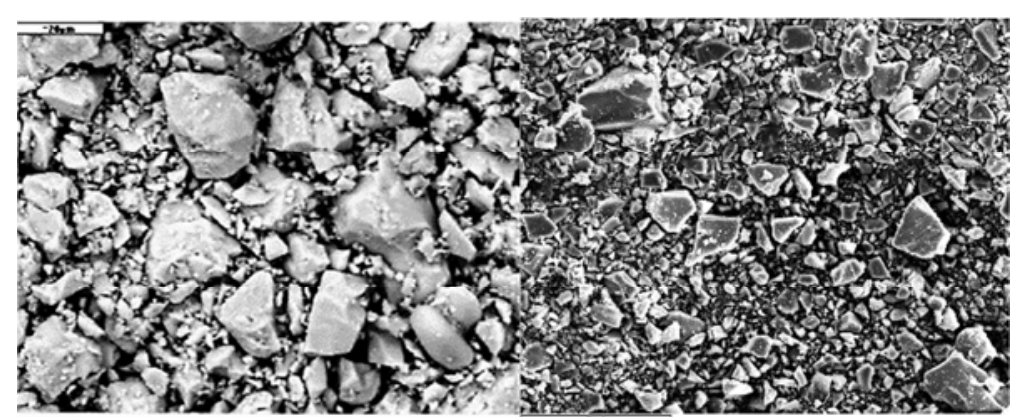

(a) Cement

(b) Glass Powder

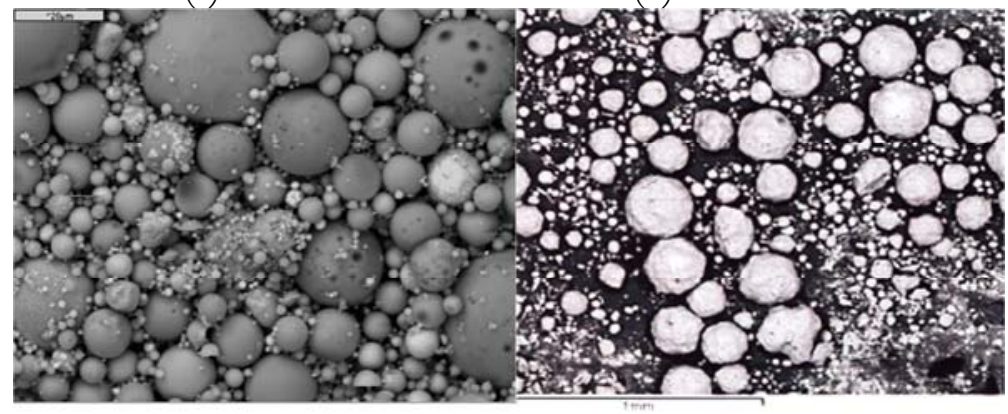

(c) Fly Ash

(d) Silica Fume

Fig. 1. Scanning electron microscopy images showing particle shapes of (a) cement, (b) glass powder, (c) fly ash, and (d) silica fume.

\subsection{Aggregate}

The coarse aggregate used in this study was crushed limestone with a maximum nominal size of $19 \mathrm{~mm}$. The coarse aggregate absorption was $0.75 \%$. The fine aggregate was natural river sand with a fineness modulus of 2.65 . The maximum size was $4.75 \mathrm{~mm}$. The aggregate absorption value was $0.51 \%$. 


\subsection{Chemical Admixture}

This study used water-reducing and -retarding chemical admixtures of Type D following ASTM C494 [17]. The chemical admixture used in the experiment was a hydroxylated organic base. The specific gravity of the admixture was 1.15. The type $\mathrm{D}$ admixture was used to delay the setting time of concrete for concreting in hot weather and for extending the delivery time of ready-mixed industrial concrete in Thailand. The dosage of the chemical admixture used in this study is $4 \mathrm{cc} / 1 \mathrm{~kg}$ cement.

\section{Experimental Methodology and Concrete Mix Proportions}

\subsection{Fresh Concrete Properties}

To ensure that concrete containing glass powder can be used in the ready-mixed concrete production process, the fresh concrete properties (setting time and slump) were tested before casting to compare the workability of the mix designs. The mix proportions of the fresh concrete used in the property testing are shown in Table 3.

The setting time test followed ASTM C403 [18], and the slump test followed the ASTM C143 standard test method [19].

In Thailand, the standard delivery time for ready-mixed concrete is $30-60 \mathrm{~min}$. Thus, in this study the slump test was conducted in the initial stage, at $30 \mathrm{~min}$ and $60 \mathrm{~min}$.

Table 3. Proportions of concrete mixtures used in tests of setting time, slump, and compressive strength $\left(\mathrm{kg} / \mathrm{m}^{3}\right)$.

\begin{tabular}{|c|c|c|c|c|c|c|c|c|c|}
\hline $\mathrm{W} / \mathrm{B}$ & Mix & $\begin{array}{c}\text { OPC } \\
\text { (kg) }\end{array}$ & $\begin{array}{c}\text { GP } \\
(\mathrm{kg})\end{array}$ & $\begin{array}{c}\text { FA } \\
(\mathrm{kg})\end{array}$ & $\begin{array}{c}\mathrm{SF} \\
(\mathrm{kg})\end{array}$ & $\begin{array}{c}\text { Water } \\
\text { (kg) }\end{array}$ & $\begin{array}{c}\text { Sand } \\
(\mathrm{kg})\end{array}$ & $\begin{array}{c}\text { Rock } \\
\text { (kg) }\end{array}$ & $\begin{array}{l}\text { Type D } \\
\text { (cc) }\end{array}$ \\
\hline \multirow{6}{*}{0.67} & $\mathrm{OPC}$ & 300 & 0 & 0 & 0 & 200 & 820 & 1080 & 1200 \\
\hline & FA10 & 270 & 0 & 30 & 0 & 200 & 800 & 1080 & 1080 \\
\hline & FA20 & 240 & 0 & 60 & 0 & 200 & 800 & 1080 & 960 \\
\hline & GP10 & 270 & 30 & 0 & 0 & 200 & 810 & 1080 & 1080 \\
\hline & GP20 & 240 & 60 & 0 & 0 & 200 & 800 & 1080 & 960 \\
\hline & SF10 & 270 & 0 & 0 & 30 & 200 & 820 & 1080 & 1080 \\
\hline \multirow{6}{*}{0.50} & $\mathrm{OPC}$ & 400 & 0 & 0 & 0 & 200 & 760 & 1050 & 1600 \\
\hline & FA10 & 360 & 0 & 40 & 0 & 200 & 750 & 1050 & 1440 \\
\hline & FA20 & 320 & 0 & 80 & 0 & 200 & 750 & 1050 & 1280 \\
\hline & GP10 & 360 & 40 & 0 & 0 & 200 & 750 & 1050 & 1440 \\
\hline & GP20 & 320 & 80 & 0 & 0 & 200 & 750 & 1050 & 1280 \\
\hline & SF10 & 360 & 0 & 0 & 40 & 200 & 250 & 1050 & 1440 \\
\hline \multirow{6}{*}{0.40} & OPC & 500 & 0 & 0 & 0 & 200 & 700 & 1020 & 2000 \\
\hline & FA10 & 450 & 0 & 50 & 0 & 200 & 690 & 1020 & 1800 \\
\hline & FA20 & 400 & 0 & 100 & 0 & 200 & 690 & 1020 & 1600 \\
\hline & GP10 & 450 & 50 & 0 & 0 & 200 & 700 & 1020 & 1800 \\
\hline & GP20 & 400 & 100 & 0 & 0 & 200 & 690 & 1020 & 1600 \\
\hline & SF10 & 450 & 0 & 0 & 50 & 200 & 690 & 1020 & 1800 \\
\hline
\end{tabular}




\subsection{Hardened Concrete Properties}

\subsubsection{Compressive Strength}

For the compressive strength test, cubic concrete specimens $10 \times 10 \times 10 \mathrm{~cm}^{3}$ in size, in accordance with BS-EN 12390-2:2000 [20], were prepared and tested at 1, 3, 7, 14, and 28 days. The mixture proportions contained $10 \%$ or $20 \%$ glass powder, $10 \%$ or $20 \%$ fly ash, or $10 \%$ silica fume. The water-to-binder ratio $(\mathrm{W} / \mathrm{B})$ was $0.40,0.50$, or 0.67 . Before compressive strength testing, the specimens were placed in water at $20^{\circ} \mathrm{C}$ for curing. The concrete mix proportions used for this test are shown in Table 3 .

\subsubsection{Ability to Resist Chloride Penetration}

To compare the ability to resist chloride penetration, quick tests were conducted in accordance with ASTM C1202 [21]. Before the experiment, each specimen was submerged in water for 14 and 28 days. The concrete mix proportions used in this test are shown in Table 4.

\subsubsection{Drying Shrinkage}

Drying shrinkage testing was conducted on a prism size of $7.5 \times 7.5 \times 28 \mathrm{~cm}^{3}$ in accordance with AS 1012.13-1992 [22]. Each specimen was cured in a lime-saturated solution for 7 days and then stored in a control chamber at $23 \pm 1{ }^{\circ} \mathrm{C}$ and a humidity of $45 \%-55 \%$. The specimen length was measured until the specimens were 75 days old. The concrete mix proportions used in this test are shown in Table 4.

Table 4. Proportions of concrete mixtures used in durability tests $\left(\mathrm{kg} / \mathrm{m}^{3}\right)$.

\begin{tabular}{|c|c|c|c|c|c|c|c|c|c|}
\hline $\mathbf{W} / \mathbf{B}$ & Mix & $\begin{array}{l}\text { OPC } \\
(\mathrm{kg})\end{array}$ & $\begin{array}{c}\text { GP } \\
(\mathrm{kg})\end{array}$ & $\begin{array}{c}\text { FA } \\
(\mathrm{kg})\end{array}$ & $\begin{array}{c}\text { SF } \\
(\mathrm{kg})\end{array}$ & $\begin{array}{c}\text { Water } \\
(\mathrm{kg})\end{array}$ & $\begin{array}{c}\text { Sand } \\
(\mathrm{kg})\end{array}$ & $\begin{array}{c}\text { Rock } \\
\text { (kg) }\end{array}$ & $\begin{array}{l}\text { Type D } \\
\text { (cc) }\end{array}$ \\
\hline \multirow{6}{*}{0.67} & OPC & 300 & 0 & 0 & 0 & 200 & 820 & 1080 & 1200 \\
\hline & FA10 & 270 & 0 & 30 & 0 & 200 & 800 & 1080 & 1080 \\
\hline & FA20 & 240 & 0 & 60 & 0 & 200 & 800 & 1080 & 960 \\
\hline & GP10 & 270 & 30 & 0 & 0 & 200 & 810 & 1080 & 1080 \\
\hline & GP20 & 240 & 60 & 0 & 0 & 200 & 800 & 1080 & 960 \\
\hline & SF10 & 270 & 0 & 0 & 30 & 200 & 800 & 1080 & 1080 \\
\hline \multirow{6}{*}{0.44} & OPC & 450 & 0 & 0 & 0 & 200 & 740 & 1030 & 1800 \\
\hline & FA10 & 405 & 0 & 45 & 0 & 200 & 720 & 1030 & 1620 \\
\hline & FA20 & 360 & 0 & 90 & 0 & 200 & 720 & 1030 & 1440 \\
\hline & GP10 & 405 & 45 & 0 & 0 & 200 & 730 & 1030 & 1620 \\
\hline & GP20 & 360 & 90 & 0 & 0 & 200 & 720 & 1030 & 1440 \\
\hline & SF10 & 405 & 0 & 0 & 45 & 200 & 720 & 1030 & 1620 \\
\hline
\end{tabular}

\section{Experimental Results}

\subsection{Fresh Concrete Properties}

\subsubsection{Setting Time}

The measured stiffening and initial setting times of each mixture are shown in Figs. 2-4. When the cement in concrete was replaced with glass powder, fly ash, or silica fume, the initial setting time was found to be reduced significantly compared to that of OPC concrete. Concrete with silica fume had the fastest setting time, whereas concrete containing glass powder had roughly the same setting time as concrete containing 
fly ash at the same replacement level. Thus, in concrete production, if the same setting time is needed, the dosage of the admixture and the water amount should be adjusted.

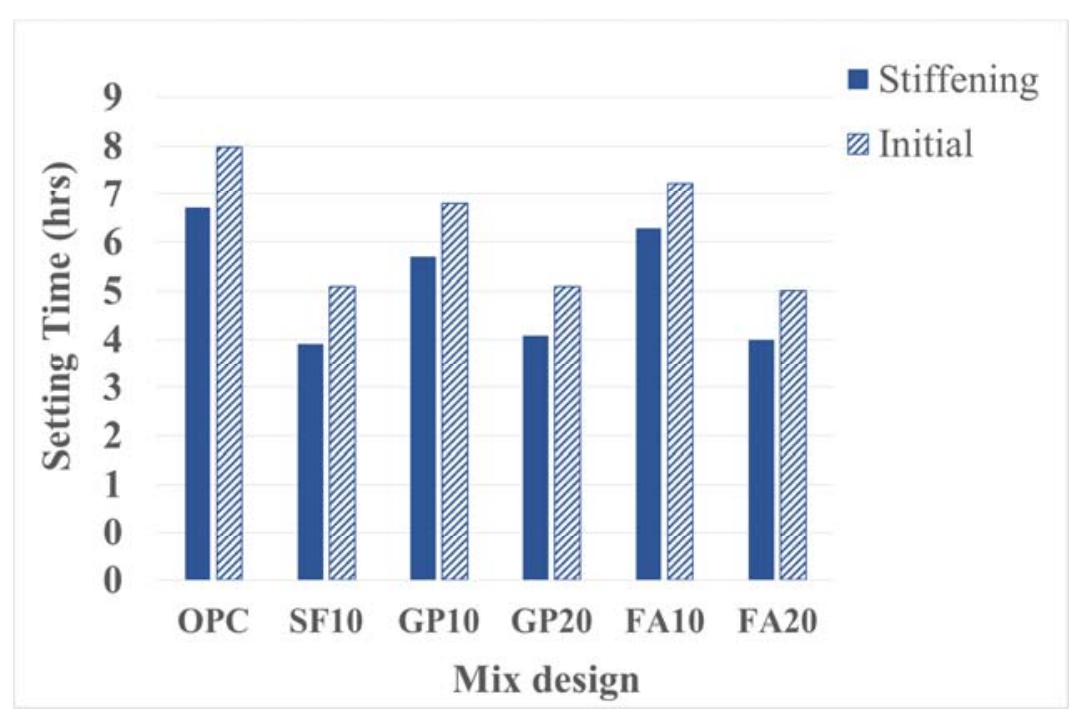

Fig. 2. Stiffening and initial setting time of mix design W/B 0.67.

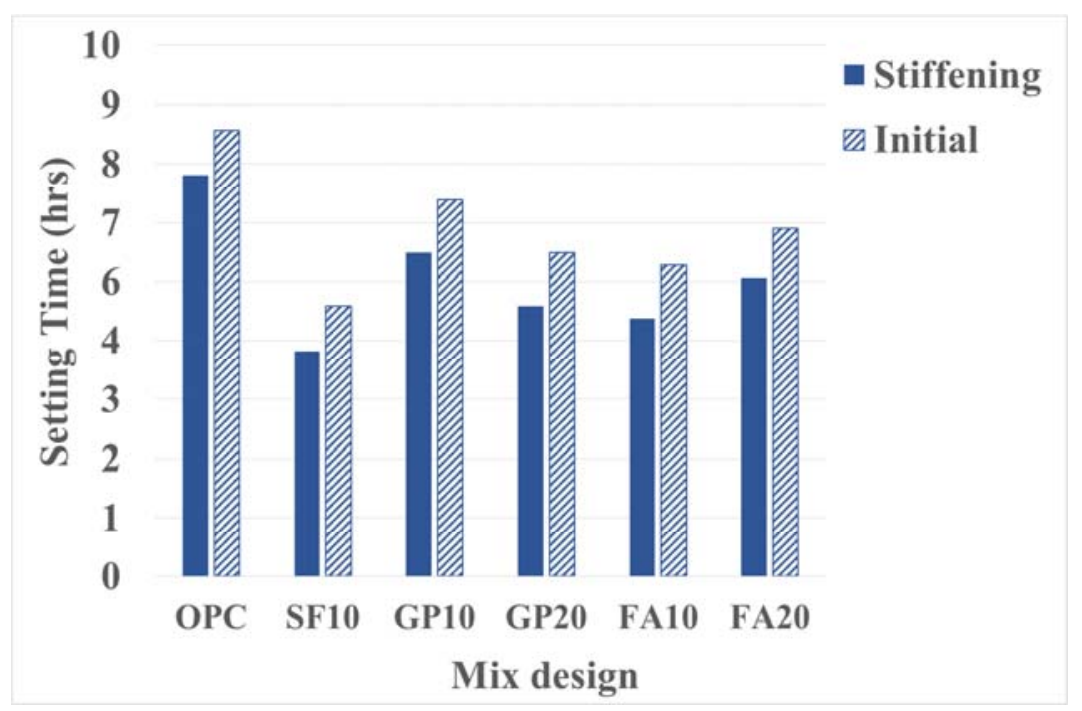

Fig. 3. Stiffening and initial setting time of mix design W/B 0.50 . 


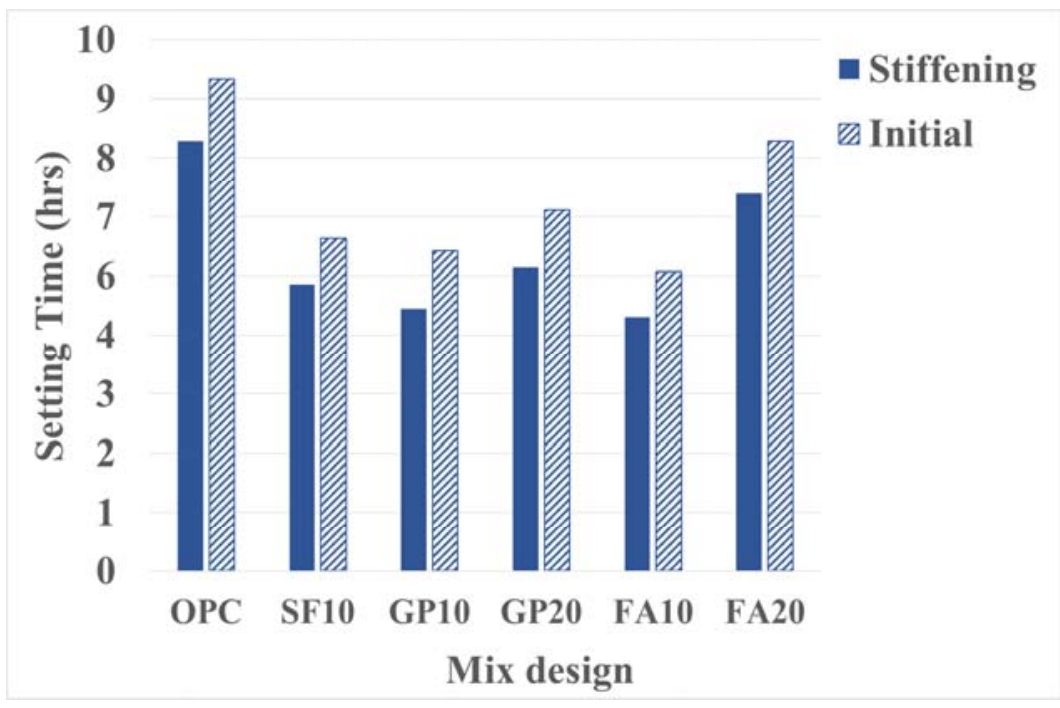

Fig. 4. Stiffening and initial setting time of mix design W/B 0.40 .

\subsubsection{Slump and Slump Retention}

Figs. 5-7 show the slump values of each concrete mixture in the initial stage and after mixing for 30 min and $60 \mathrm{~min}$. The results show that concrete that contains fly ash as an additive has a higher initial slump than normal concrete. When concrete has the same amount of water and same chemical admixture dosage, fly ash can increase the initial workability after mixing. However, the slump value after 30 min remains the same as that of normal concrete. A previous review reported that fly ash can reduce the friction between cement and aggregates, resulting in greater workability of fresh concrete [4] in the initial stage.

For concrete containing glass powder and silica fume, the slump values decreased, especially at $30 \mathrm{~min}$ and $60 \mathrm{~min}$. The slump values were lower when a higher proportion of glass powder was used. This is because the sharp, irregular geometric forms of the glass particles may increase the frictional force between the particles, decreasing the fluidity [11].

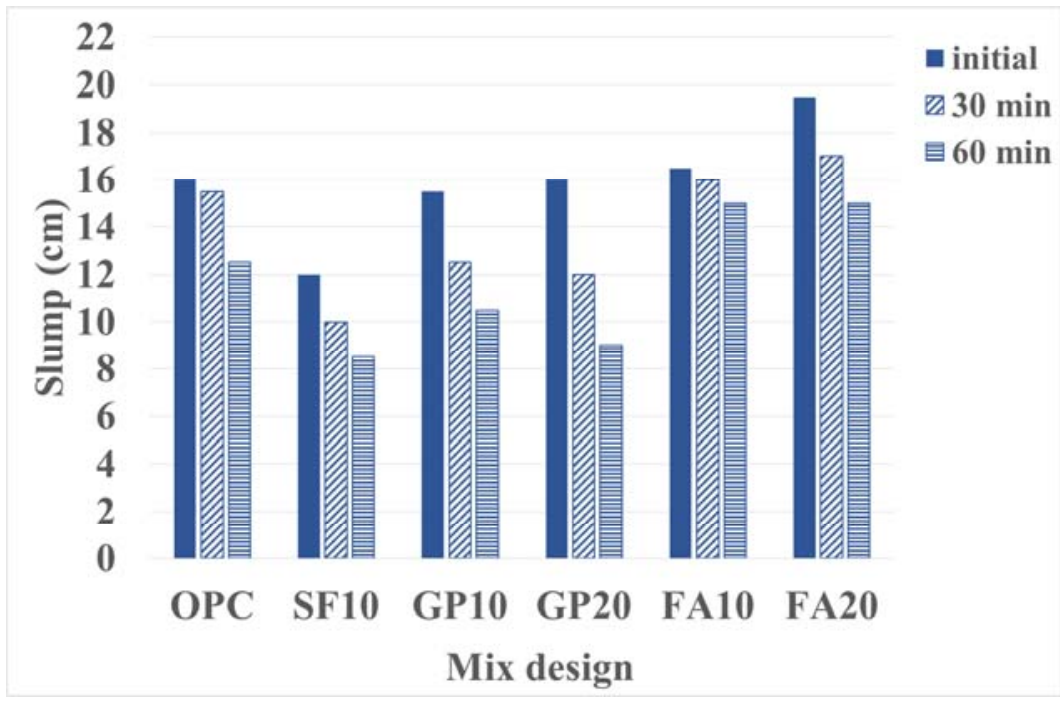

Fig. 5. Slump of mix design W/B 0.67 . 


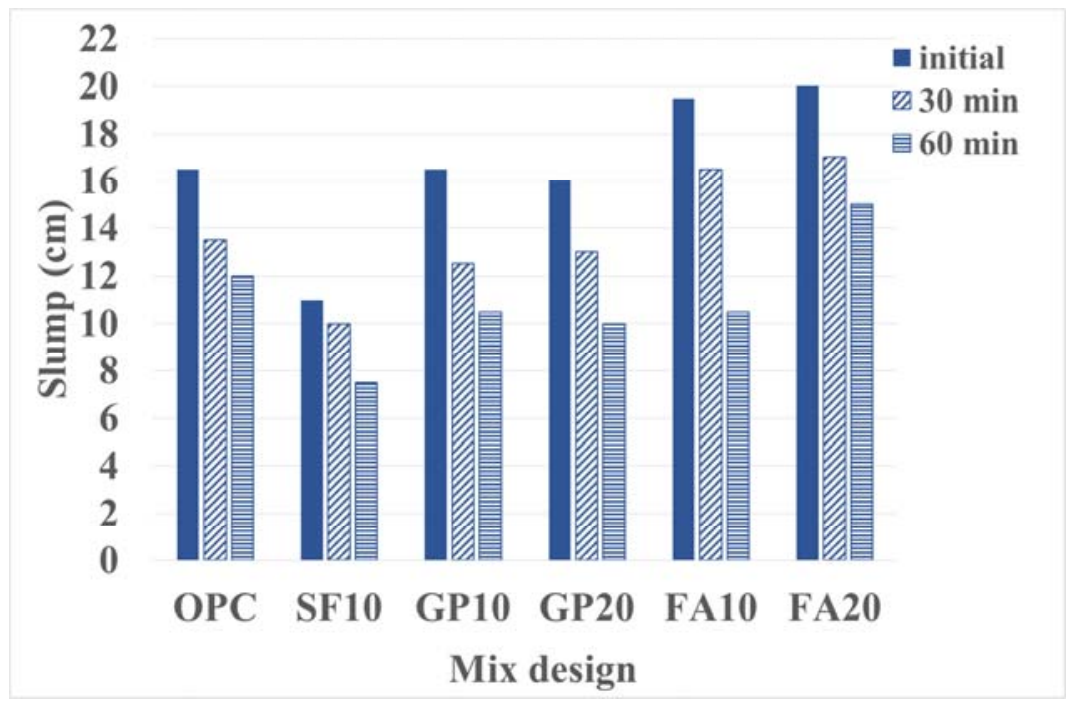

Fig. 6. Slump of mix design W/B 0.50 .

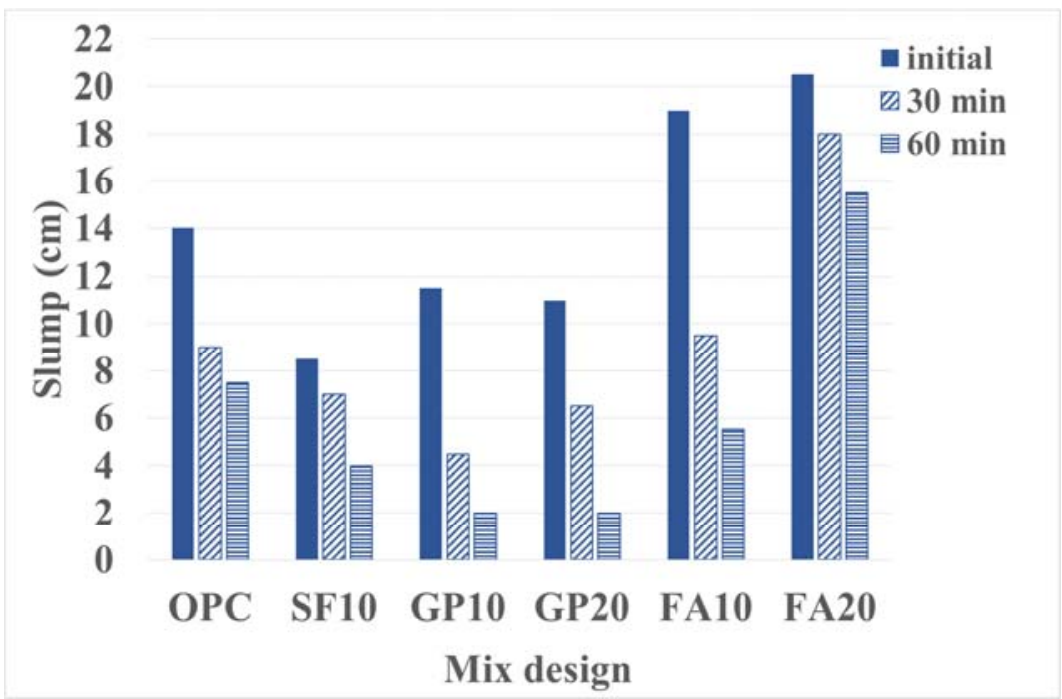

Fig. 7. Slump of mix design W/B 0.40.

\subsection{Hardened Concrete Properties}

\subsubsection{Compressive Strength}

Figs. 8-10 show the compressive strength development for all the concrete mixtures. The compressive strength of concrete with $10 \%$ finely ground glass powder as the cement replacement seems to be higher than that of pure cement at 1 and 28 days and greater than that of the other mixtures.

The glass powder used in this study had smaller particles than the other cementitious materials; therefore, these small particles can fill the space between the particles in the concrete and improve the compressive strength at 1 day. Furthermore, a previous review reported that glass powder has a smooth surface that does not absorb water inside concrete. Therefore, the negligible water absorption of glass powder can provide more water for cement hydration in the early stage, which might increase the compressive strength [5].

The testing results show that the compressive strength of concrete containing glass powder, fly ash, and silica fume tends to increase after 28 days. However, for the OPC concrete without a pozzolan material, the rate of strength development decreased after 28 days. 
The results show that adding 10\% glass powder to the concrete improved the compressive strength more than adding fly ash at the same replacement level, and concrete containing $20 \%$ glass powder exhibits the same level of strength development as that containing $20 \%$ fly ash.

The experimental results also showed that adding $10 \%$ or $20 \%$ glass powder cannot improve the strength development at 3-28 days as much as adding silica fume. Note that the strength of concrete containing $10 \%$ glass powder at an age of 1 day is the same as or slightly higher than that of concrete containing densified silica fume because of the filler effect.

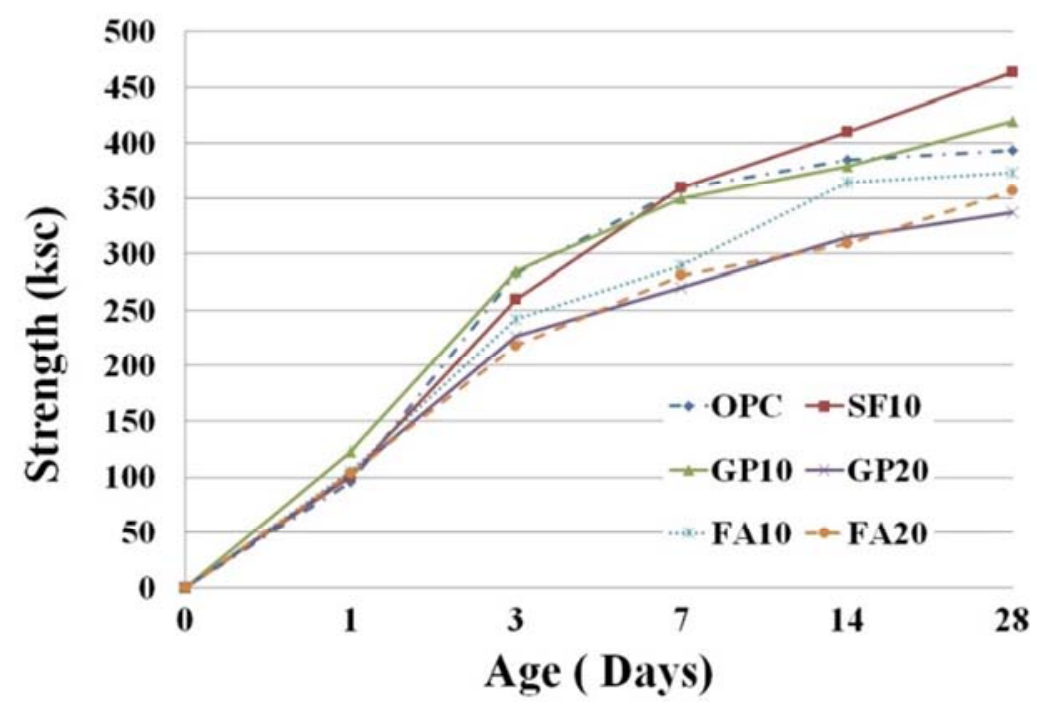

Fig. 8. Compressive strength of concrete W/B 0.67.

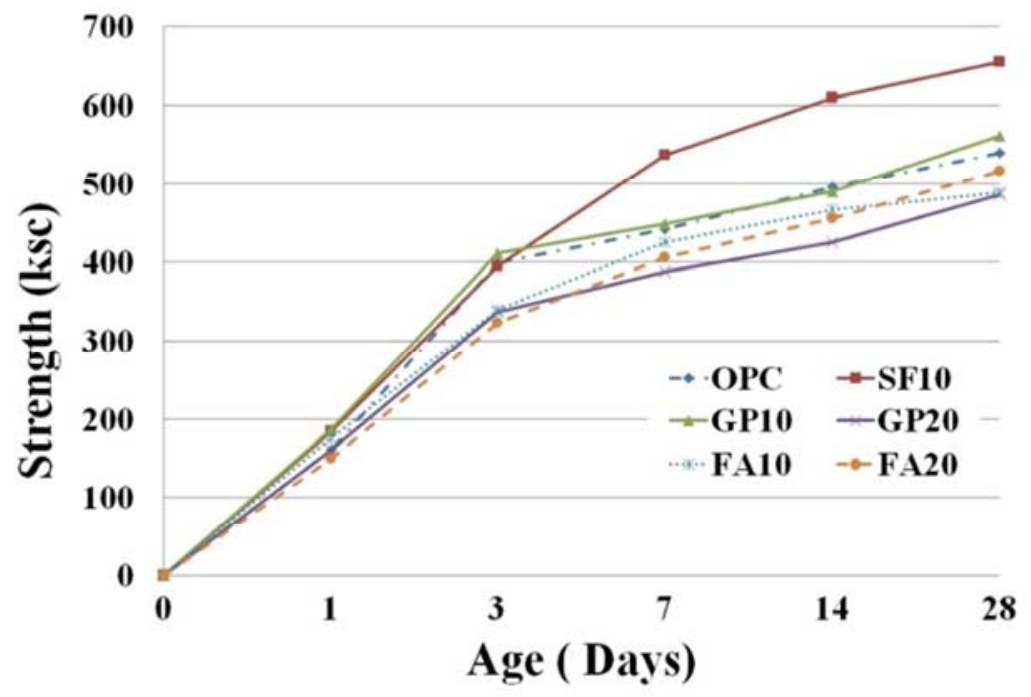

Fig. 9. Compressive strength of concrete W/B 0.50. 


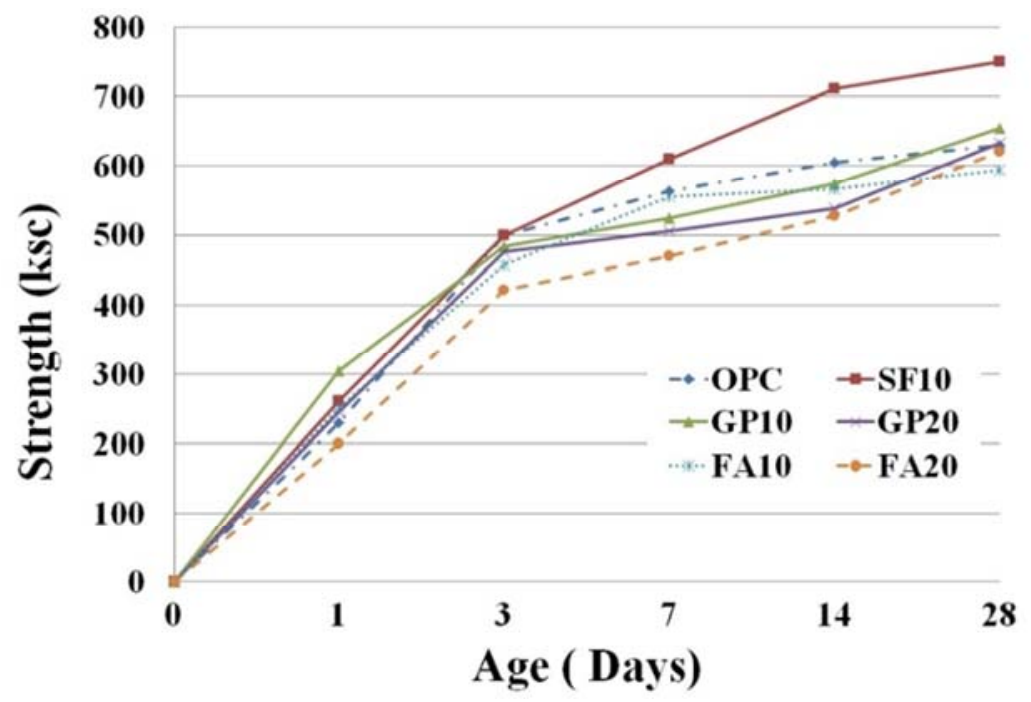

Fig. 10. Compressive strength of concrete W/B 0.40.

\subsubsection{Ability to Resist Chloride Penetration}

Figs. 11 and 12 show the Coulomb charge passed through the concrete specimens by chloride ions. For the 14-day-old specimens, the testing results show that adding pozzolan can reduce the Coulomb charge passed through the concrete.

The reduction in the charge passed by concrete with $10 \%$ glass powder was roughly the same as that of concrete containing $10 \%$ fly ash, but concrete with $20 \%$ glass powder showed a greater reduction in the charge passed than concrete containing fly ash at the same replacement level in both W/B 0.67 and 0.44.

The charge passed is lower at 28 days than at 14 days for all the mixtures. The results show that concrete containing glass powder can exhibit lower Coulomb charge and has a lower value than concrete containing fly ash at the same replacement level in both W/B 0.67 and 0.44 . However, the glass powder cannot reduce the value to that of concrete containing silica fume.

The testing results show that the glass powder increased the ability to resist chloride penetration at 28 days to about the same degree as fly ash at the same replacement level.

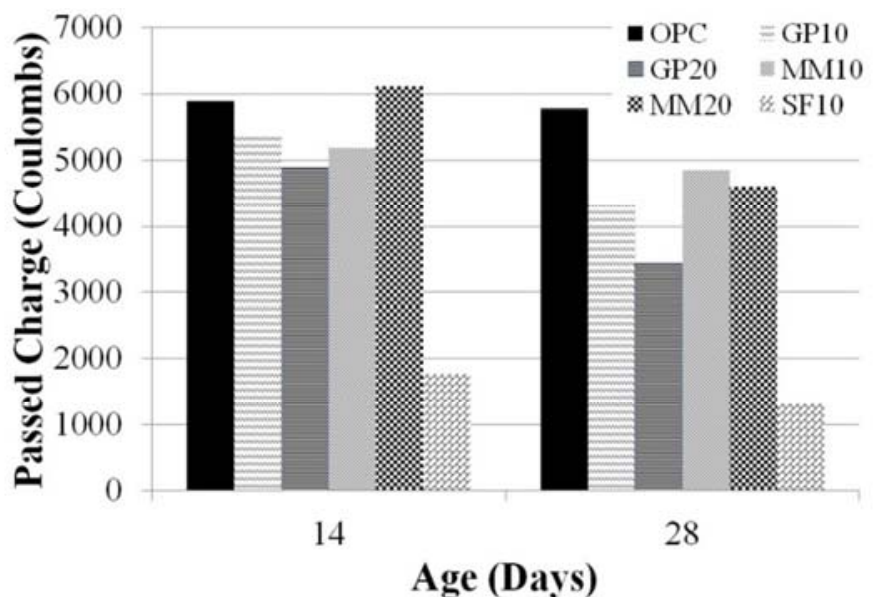

Fig. 11. Coulomb charge passed through concrete W/B 0.67. 


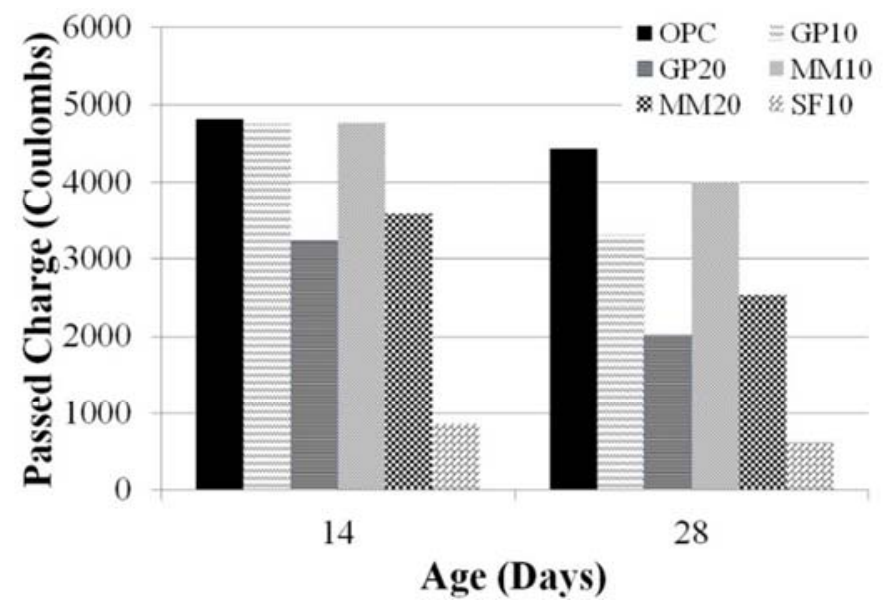

Fig. 12. Coulomb charge passed through concrete W/B 0.44.

\subsubsection{Drying Shrinkage}

Figs. 13 and 14 show the drying shrinkage values obtained in this study. The results show that concrete containing $10 \%$ glass powder had lower shrinkage than all the other mixtures used in this study at 28 days, but at 75 days, the concrete containing silica fume had the lowest value for both W/B 0.67 and 0.44 .

For concrete W/B 0.67 at 75 days, the concrete without pozzolan had the highest shrinkage for all the mixture proportions, and the concrete containing glass powder had lower shrinkage than that containing fly ash at the same replacement level. However, the use of glass powder cannot reduce the shrinkage as well as the use of silica fume.

For concrete W/B 0.44 at 75 days, concrete with $10 \%$ glass powder had lower shrinkage than concrete containing fly ash at the same replacement level. However, concrete containing $20 \%$ glass powder had higher shrinkage than that with $20 \%$ fly ash.

As mentioned above, a previous review reported negligible water absorption by glass powder (less than that by fly ash); therefore, glass powder can provide more water for cement hydration [5]. Consequently, the hydrated product in concrete will be increased, and the water in capillary pores will be reduced.

Drying shrinkage in concrete occurs because of the evaporation of water in concrete. Concrete with less water in the pores and a higher hydrated product tends to exhibit lower shrinkage.

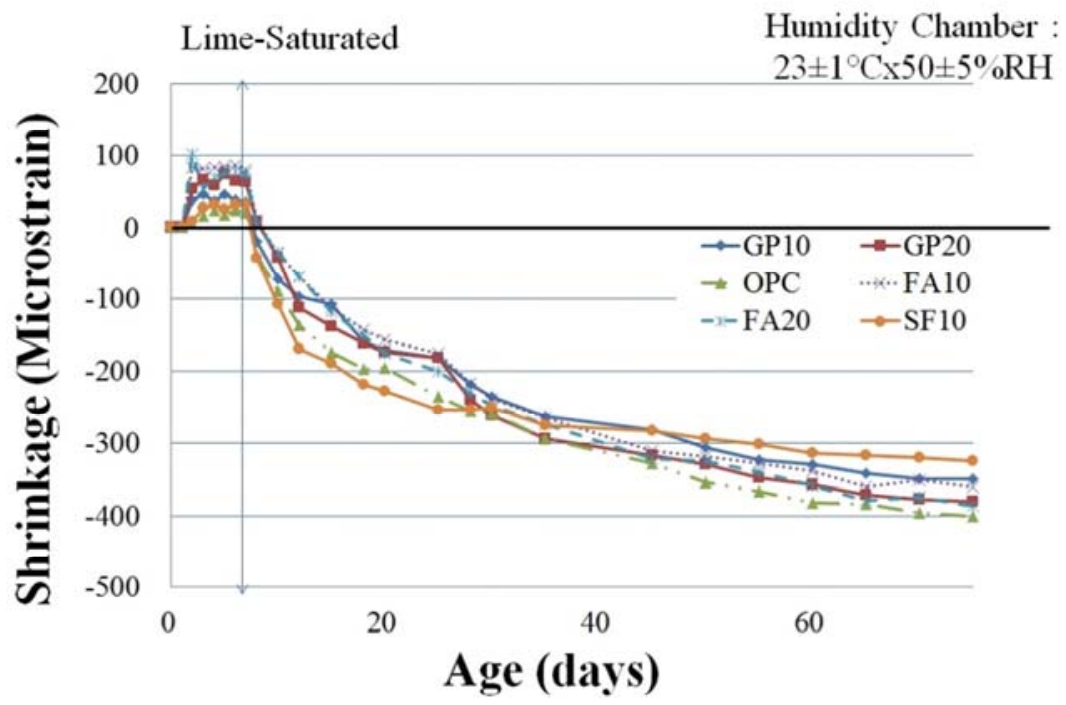

Fig. 13. Drying shrinkage of concrete W/B 0.67. 


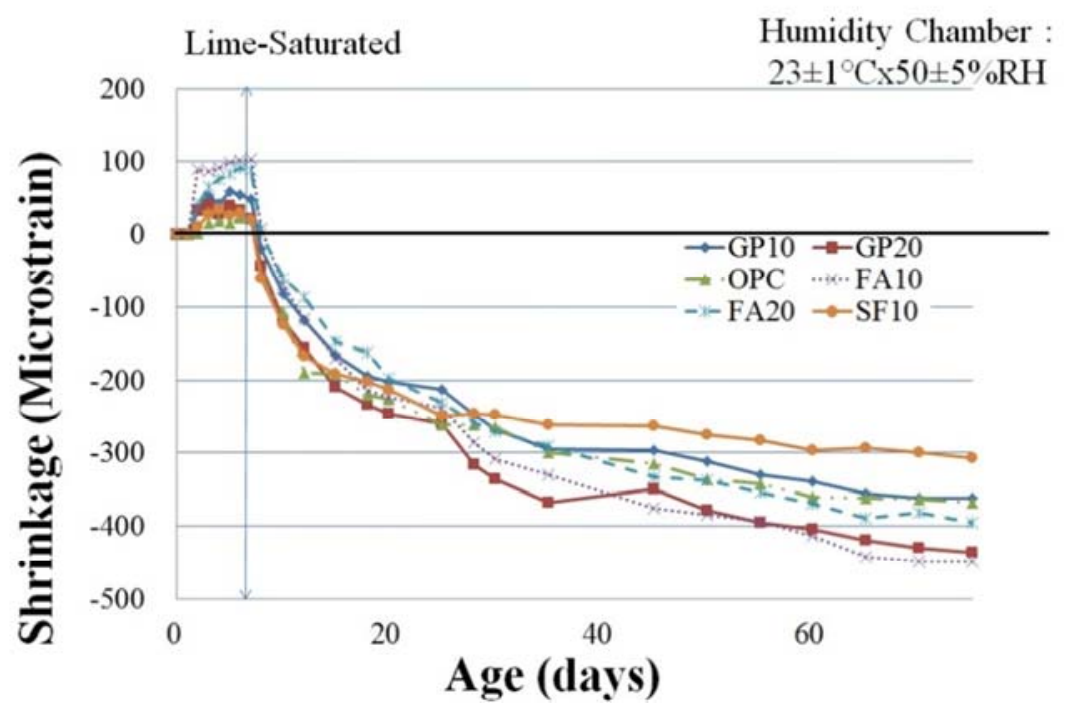

Fig. 14. Drying shrinkage of concrete W/B 0.44.

\section{Conclusion}

This study showed that concrete containing glass powder has a shorter setting time and lower slump than normal concrete and concrete containing fly ash. Thus, for application at a construction site, the dosage of the chemical admixture should be adjusted to maintain the same level of workability and working time.

Concrete containing 10\% finely ground glass powder (approximate mean diameter, $12-15 \mu \mathrm{m}$ ) exhibited greater compressive strength at an age of 1 day. Glass powder can be used as a cementitious additive in concrete and can perform as well as fly ash at the same replacement level in terms of the compressive strength, but glass powder cannot improve the strength level as much as silica fume can. Furthermore, glass powder can improve the ability to resist chloride ions. The testing results show that glass powder can reduce the Coulomb charge passing through the concrete better than fly ash at the same replacement level at ages of 14 and 28 days.

Glass powder $(10 \%)$ can reduce the amount of drying shrinkage after 75 days compared with that of pure cement concrete and concrete containing fly ash at the same replacement level when the mixture proportion has the same amount of binder and water, but concrete with $10 \%$ silica fume can reduce the amount of shrinkage better than concrete with glass powder at the same replacement level.

\section{References}

[1] Pat Gibbons. Poz:olans for Lime Mortars, The Conservation and Repair of Ecclesiastical Buildings, 1997. Online at: http://www.buildingconservation.com/articles/pozzo/pozzo.htm

[2] P. K. Mehta, and P. J. M. Monteiro, "Admixture" in Concrete: Microstructure, Properties, and Materials, 3rd ed., New York, McGraw - Hill, 2006, ch. 8, pp. 295-307.

[3] National Ready Mixed Concrete Association, CIP30-Supplementary Cementitious Materials, Concrete in Practice. Online at: http://www.nrmca.org/aboutconcrete/cips/30p.pdf

[4] V. Sataa, C. Jaturapitakkulb, and K. Kiattikomolb, "Influence of pozzolan from various by-product materials on mechanical properties of high-strength concrete," Construction and Building Materials, vol. 21, no. 7, pp. 1589-1598, 2007.

[5] Shao Y. et al., "Studies on concrete containing ground waste glass," Cement and Concrete Research, vol. 30, 2000.

[6] A. Shayan, "Value-added utilisation of waste glass in concrete", in LABSE Symposium., Melbourne, 2002.

[7] C. Shi, and K. Zheng, "A review on the use of waste glasses in the production of cement and concrete," Resources, Conservation and Recycling, vol. 52, pp. 234-247, 2007. 
[8] N. Schwarz, H. Cam, and N. Neithalath, "Influence of a fine glass powder on the durability characteristics of concrete and its comparision to fly ash," Cement and Concrete Composites, vol. 30, pp. 486-496, 2008.

[9] M. Liu, "Incorporating ground glass in self-compacting concrete," Construction and Building Materials, vol. 25, pp. 919-925, 2011.

[10] J. M. Khatib, E. M. Negim, H. S. Sohl, and N. Chileshe, "Glass powder utilisation in concrete production," European Journal of Applied Sciences, vol. 4(4), pp. 173-176, 2012.

[11] G. Vijayakumar, H. Vishaliny, and D. Govindarajulu, "Studies on glass powder as partial replacement of cement in concrete production," International Journal of Emerging Technology and Advanced Engineering, vol. 3(2), pp. 153-157, 2013.

[12] S. Abdallah, and M. Fan, "Characteristics of concrete with waste glass as fine aggregate replacement," International Journal of Engineering and Technical Research (IJETR), vol. 2(6), pp. 11-17, 2014.

[13] A. Shayan, and A. Xu, "Performance of glass powder as a pozzolanic material in concrete: A field trial on concrete slabs," Cement and Concrete Research, vol. 36, pp. 457-468, 2006.

[14] S. Banjongkliang, and B. Stitmannaithum, "Potential of using glass powder as pozzolan," in Annual Concrete Conference 8 (ACC8), Chonburi, Thailand, 2006. (In Thai)

[15] Pollution Control Department, "The report of pollution situation in Thailand," Ministry of Natural Resources and Environment, Bangkok, 2009. (In Thai)

[16] ASTM C1240, "Standard specification for silica fume used in cementitious mixtures," 2005.

[17] ASTM C494, "Standard specification for chemical admixtures for concrete," 2010.

[18] ASTM C403, "Standard test method for time of setting of concrete mixtures by penetration resistance," 2008.

[19] ASTM C143, "Standard test method for slump of hydraulic-cement concrete," 2010.

[20] BS-EN 12390-2:2000, "Testing hardened concrete: Making and curing specimens for strength tests," 2000.

[21] ASTM C1202, "Standard test method for electrical indication of concrete's ability to resist chloride ion penetration," 2010.

[22] AS 1012.13-1992, "Methods of testing concrete - Determination of the drying shrinkage of concrete for samples prepared in the field or in the laboratory," 1992. 
